\title{
ARTICLE
}

\section{Skandia America and VAT Grouping in Spain}

\author{
Estefanía López Llopis*
}

\begin{abstract}
For the first time since the publication of the Court of Justice of the European Union's (CJEU's) decision in Skandia America, a Spanish administrative authority has spoken out explicitly about the impact of such a judgment on Spain. With its resolution, the Spanish administrative authority reopened a closed debate when pointing out that it would be totally inadmissible to reject the application of the Skandia America case to the Spanish legal system only as a result of the particular manner that Article 11 of the VAT Directive has been implemented by the Spanish legislator. This article analyses the problems and doubts concerning the application of the Skandia America judgment to VAT groups constituted under the Spanish VAT Act. To do so, this article performs a three-step analysis. First, the arguments presented by the CJEU to justify its decision in such a judgment are reviewed. Secondly, the author provides a description of the VAT grouping scheme that is applicable in Spain. Finally, the attention is focused on the reasoning offered by the Spanish administrative authority in its resolution to support the fact that the Skandia America judgment is fully applicable to VAT groups located in Spain.
\end{abstract}

Keywords: EU Law, VAT Directive, VAT grouping, branch, fixed establishment, head office, supply of services, single taxable person, intra-group transaction, principle of subsidiarity.

\section{INTRODUCTION}

According to Article 11 of the VAT Directive:

After consulting the advisory committee on value added tax (hereafter, the VAT Committee), each Member State may regard as a single taxable person any persons established in the territory of that Member State who, while legally independent, are closely bound to one another by financial, economic and organisational links.

The lack of further specification about the way this faculty must be exercised has obligated the Court of Justice of the European Union (hereinafter CJEU) to interpret that provision on more than one occasion.

One of the most important judgments of the European Court concerning the issue of VAT grouping was delivered in the so-called Skandia America case. ${ }^{1}$ It addresses the case of a non-EU company that supplies services to its Swedish branch that is a member of a VAT group in Sweden. According to the court, the consideration of the group as a single taxable person entails a breakdown in the legal relationship previously existing between the fixed establishment and its head office. This interpretation brings about two important consequences. On the one hand, it makes it impossible to consider these two entities (that is, the non-EU head office and its fixed establishment in Sweden) as a single taxable person (as was maintained by the CJEU in FCE Bank); on the other hand, the supply of services from the head office to its fixed establishment (which must no longer be understood as supplied to the fixed establishment but to the group itself) are ensconced within the scope of VAT.

The potential application in Spain of the decision made by the CJEU in Skandia America is, at the very least, questionable. This is due to the fact that the particular technique used by the Spanish legislator to implement a VAT grouping scheme into the national legislation raises serious doubts concerning its compatibility with EU Law. In January 2020, however, the Spanish Central EconomicAdministrative Court (hereinafter TEAC) ${ }^{2}$ reopened a closed debate when pointing out that it would be totally

\section{Notes}

Assistant professor at the University of Alicante (Spain). Email: estefania.lopez@ua.es.

For other important judgments in this field, see CJEU, 22 May 2008, Case C-162/07, Ampliscientifica, ECLI:EU:C:2008:301; CJEU, 9 Apr. 2013, Case C-85/11, Commission v. Ireland, ECLI:EU:C:2013:217; CJEU, 25 Apr. 2013, Case C-480/10, Commission v. Sweden, ECLI:EU:C:2013:263; CJEU, 16 July 2015, Joined Cases C-108/14 and C-109/ 14, Larentia + Minerva, ECLI:EU:C:2015:496.

Despite its name, Economic Administrative Courts are not judicial bodies or national courts. Although functionally independent, they are integrated in the Spanish Ministry of Finance and Civil Service. They are responsible for resolving economic administrative claims, a special resource to contest tax acts before the Spanish Tax Administration. The Spanish Central Economic-Administrative Court, to which this article refers, is headquartered in Madrid and extends its powers throughout the entire country. 
inadmissible to reject the application of the Skandia America case purely and simply as a result of the particular manner that Article 11 of the VAT directive has been implemented in Spain.

This article analyses the problems and uncertainties concerning the application of the Skandia America judgment to the Spanish legal system with a three-step analysis. First, a revision is made of the arguments proposed by the CJEU to justify its decision in such a judgment; second, the article offers a description of the VAT grouping scheme that is applicable in Spain; and, finally, the author focuses on the reasoning presented by the Spanish TEAC in order to support the fact that the Skandia America judgment is fully applicable to VAT groups located in Spain

\section{Eu CASE-LAW WITH REgARD TO BRANCHES AND VAT GROUPS}

\section{I CJEU, 23 March 2006, Case C-210104, FCE Bank}

It must be admitted that the FCE Bank judgment contains no specific references to VAT grouping. Its significance in this context, however, is undeniable. On the one hand, the FCE Bank judgment elucidates the existing relationship between a company and its fixed establishments abroad (taking into consideration that both the company and the fixed establishments could belong to a VAT group in their Member State of origin). On the other hand, the examination of the reasoning in FCE Bank contributes to an improved understanding of the arguments introduced by the CJEU within the framework of Skandia America.

The FCE Bank judgment describes the case of two entities: the FCE Bank located in the United Kingdom and its secondary establishment FCE IT situated in Italy. During a number of specific years, the FCE Bank supplied its branch with a variety of services that were considered to fall within the scope of VAT. ${ }^{3}$ FCE IT 'claimed repayment of the VAT on those supplies ... on the basis of invoices which it issued to itself (a process known as "selfinvoicing"), 4

The implied refusal of the branch's application by the Italian tax authorities gave rise to an extensive proceeding. The case reached the Italian Supreme Court of Cassation that decided to stay the proceedings and refer a number of questions for a preliminary ruling. The aim was, essentially, to clarify whether the transactions between the fixed establishment and its head office should be regarded as being encapsulated within the scope of VAT.

In response to the first question and having qualified FCE IT as a secondary establishment of the FCE Bank with no legal personality of its own, the court notes that, according to case-law, a provision of services is taxable only if there exists between the service provider and the recipient a legal relationship in which there is a reciprocal performance'. 5 The application of this premise to the case in the main proceedings requires verifying whether the Italian branch of the FCE Bank 'may be regarded as an independent bank, in particular in that it bears the economic risk arising from its business'. ${ }^{6}$ Only in such a case could it be qualified as a taxable person for VAT purposes differently from its head office.

The analysis of the facts, however, allows the court to conclude that it is the bank as a legal entity and not the branch that assumes the economic risks arising from the financial business 'such as, for example, a customer defaulting on the repayment of a loan' ${ }^{7}$ Actually, this is the reason why the Member State of origin supervises the branch's financial strength and solvency. As the CJEU points out in paragraph 37 of the judgment, 'FCE IT does not have any endowment capital. Consequently, the risk associated with the economic activity lies wholly with the FCE Bank. Consequently, FCE IT is dependent upon that company and, with it, constitutes a single taxable person'.

According to the above reasoning, the European Court concludes that 'a fixed establishment, which is not a legal entity distinct from the company of which it forms part, established in another Member State and to which the company supplies services, should not be treated as a taxable person by reason of the costs imputed to it in respect of those supplies'. ${ }^{8}$

\subsection{CJEU, I7 September 2014, Case C-7/I3, Skandia America}

\subsection{Content of the Judgment}

In the Skandia America judgment, the Court of Justice tackles the issue of VAT grouping in connection with the concept of a fixed establishment for the first time. The

\section{Notes}

According to para. 15 of the FCE Bank judgment, supplies of services received from the FCE Bank include 'consultancy, management, staff training, data processing and the supply and management of application software'. CJEU, 23 Mar. 2006, Case C-210/04, FCE Bank, ECLI:EU:C:2006:196, para. 15.

FCE Bank (C-210/04), supra n. 3, para. 15.

Ibid., para. 34

Ibid., para. 35

Ibid., para. 36

Ibid., para. 41 
judgment describes the case of a multinational group of companies; amongst them, a non-EU head office (SAC) and one of its fixed establishments in the EU (Skandia Sverige). The former, located in the United States, purchases computer services on a global scale and distributes them to Skandia Sverige that is registered in Sweden as a member of a VAT group. The Swedish branch is subsequently responsible for transforming these services into a final product which is then supplied to different members in the Skandia group. A mark-up of 5\% is charged on each supply of services, both between SAC and Skandia Sverige and between the latter and other companies in the group. Concerning VAT, the services supplied by SAC to its branch were considered by the Swedish tax administration to constitute taxable transactions. According to this premise, 'Skandia Sverige was identified as also liable for VAT and it was charged the amount of tax relating to those supplies on the ground that it was SAC's branch in Sweden'? These decisions were challenged before the Stockholm Administrative Court which decided to stay the proceedings and to refer two questions for a preliminary ruling. With its first question, the referring court asked whether 'supplies of services from a main establishment in a third country to its branch in a Member State constitute taxable transactions when the branch belongs to a VAT group'. ${ }^{10}$ The CJEU begins its analysis by stating that:

According to the Court's case-law, a supply of services is taxable only if there exists between the service supplier and the recipient a legal relationship in which there is a reciprocal performance ... To establish whether such a relationship exists between a non-resident company and one of its branches established in a Member State so that the supplies made may be liable to VAT, it is necessary to determine whether the branch carries out an independent economic activity. ${ }^{11}$

At first, the assessment of the facts in the main proceedings leads the European Court to the same conclusion as in the FCE Bank case. As pointed out in paragraph 26 of the Skandia America judgment:

As a branch of SAC, Skandia Sverige does not operate independently and does not itself bear the economic risks arising from the exercise of its activity. In addition, as a branch, according to the national legislation, it does not have any capital of its own and its assets belong to SAC. Consequently, Skandia Sverige is dependent on SAC and cannot therefore itself be characterised as a taxable person within the meaning of Article 9 of the VAT Directive. ${ }^{12}$

The distinctive feature of the case when comparing Skandia America with the FCE Bank case is that Skandia Sverige belongs to a group under Swedish legislation that is considered as a single taxable person for VAT purposes and has been assigned a single VAT number by Swedish tax authorities. This key element, which is lacking (or, at least, is not expressly mentioned ${ }^{13}$ ) in FCE Bank, will not only condition the position taken by the CJEU in Skandia America but will ultimately determine its decision on the matter.

From the court's perspective, it follows from the aforementioned fact that the supplies of services made by a third party to a member of a VAT group must be considered, for VAT purposes, to have been made not to that member but to the actual VAT group to which that member belongs'. ${ }^{14}$ This statement leads to the conclusion that it is no longer possible to consider that SAC and Skandia Sverige constitute a single taxable person for VAT purposes as long as the branch belongs to a VAT group in Sweden. As a result, services supplied by the main establishment in a third country to its branch in a Member State 'constitute a taxable transaction, under Article 2(1)(c) of the VAT Directive'. ${ }^{15}$

With regards to the second question concerning the liability for the VAT that is payable, it is supported by the court that:

in a situation such as that in the main proceedings where the main establishment of a company in a third country supplies services for consideration to a branch of that company in a Member State and where that branch belongs to a VAT group in that Member State, that VAT group, as the purchaser of the services, becomes liable for the VAT payable. ${ }^{16}$

This conclusion is based on the provisions under Article 196 of the VAT Directive according to which: 'VAT shall be payable by any taxable person, or non-taxable legal

\section{Notes}

CJEU, 17 Sept. 2014, Case C-7/13, Skandia America, ECLI:EU:C:2014:2225, para. 18.

Skandia America (Case 7/13), supra n. 9, para. 21

Ibid., paras 24 and 25.

12 Ibid., para. 26.

13 See L. Selting, The Implications of Ampliscientifica for VAT Groups in the EU, 04(12) Tax Planning International: Indirect Taxes 13 (2012). See also R. Abdoelkariem \& F. Prinsen, The Interaction Between Head Office, Branch and VAT Grouping: New Challenges Abead for the European Union, 26(4) International VAT Monitor 209 (2015).

14 Skandia America (Case 7/13), supra n. 9, para. 29.

15 Ibid., para. 32.

16 Ibid., para. 38. 
person identified for VAT purposes, to whom the services referred to in Article 44 are supplied, if the services are supplied by a taxable person not established within the territory of the Member State'.

\subsubsection{Critical Remarks}

In the author's view, the Skandia America judgment is expected to play a decisive role in the field of VAT grouping. Firstly, it is undeniable that, in this judgment, the CJEU sheds new light on the knock-on effects of the single taxpayer principle on which Article 11 of the VAT Directive is based. Now, due to the new information provided by the court, it can be accepted that the application of a national VAT grouping scheme not only entails the configuration of the group as a supplier and recipient of goods and services (in the understanding that a single VAT number must be allocated to the group). It also generates a legal separation (or a dissociation) between the fixed establishments belonging to the VAT group and the companies on which they depend. As a result, the fact that a fixed establishment becomes part of a VAT group in its Member State of origin prevents such an entity from constituting a single taxable person together with its head office.

On the other hand, it appears to be clear that the CJEU's decision in Skandia America reveals a novel perspective about the nature of the existing relationship between a head office and its fixed establishments in other countries. As opposed to the traditional conception of fixed establishments being entities with no legal personality of their own (and, therefore, as a part of their head offices), the Skandia America judgment calls for a dissociation between both entities when the fixed establishment belongs to a VAT group. This decision, clearly distanced from the guidelines followed thus far by the Court of Justice, has engendered a broad debate not only among authors and scientific doctrine but also among the European institutions themselves.

To mention some of the more controversial aspects, the fact that the CJEU focuses all of its attention on the situation described by the referring court while disregarding other possibilities or combination of facts has incited some uncertainties about the possibility of transferring its decision on the case to other similar scenarios. These include, for example, those cases in which services are supplied by the fixed establishment to its head office and not the other way around; cases in which it is the head office and not the branch that belongs to a group for VAT purposes; cases in which both the head office and the fixed establishment are located in the EU; or cases in which the controversial transaction does not consist of a supply of services but a delivery of goods.

Many of the issues described above were addressed by the VAT Advisory Committee in its Working Document No 845,17 February $2015^{17}$ and by the VAT Expert Group in its report of 31 August 2015. ${ }^{18}$ Far from elucidating the existing controversy, however, the perspectives defended in those documents revealed important discrepancies about the field of application of the Skandia America judgment. In contrast to the broad interpretation supported by the VAT Committee, the VAT Expert Group showed themselves to be in favour of a more extensive interpretation of the FCE Bank principles. ${ }^{19}$

Focusing the attention on the territorial aspects, for example, the VAT Committee supports that 'the fact that the head office was established in a third country and that the branch was established in Sweden was itself unessential, but the analysis revolved around the links between entities in legal and VAT grouping terms. ${ }^{20}$ According to this reasoning:

it seems that the conclusion attained in Skandia America should not be different had the head office been established in another Member State. Even if all the entities involved were established in one and the same Member State, where the head office does not belong to the VAT group, it should be treated as an independent taxable person different from the VAT group. $^{21}$

The VAT Expert Group, on the contrary, suggests that the 'Skandia judgment should be applied only in the context of the case, and so applied only to: (1) transactions involving non-EU head offices or branches'. ${ }^{22}$

\section{Notes}

17 European Commission, Value Added Tax Committee, CJEU Case C-7/13 Skandia America: VAT Group, 845 Working Paper, taxud.c.1(2015)747072 (17 Feb. 2015), https:// circabc.europa.eu/sd/a/e75d22a9-ff84-485a-acc7-d52ada466575/845\%20-\%20Case\%20C-7-13\%20-\%20Skandia\%20America.pdf (accessed 17 Aug. 2020)

18 European Commission, Vat Expert Group, VAT grouping and judgment in Case C-7/13 (Skandia America Corp. (USA)f, 047 VEG, taxud.c.1(2015)3986774 (31 Aug. 2015), https://circabc.europa.eu/sd/a/b70c5f81-8ce1-4a87-9702-6691f83421d2/879\%20-\%20Skandia\%20America\%20case\%20-\%20Follow-up\%20VEG\%20-\%20Questions-EN. pdf (accessed 17 Aug. 2020).

19 A similar controversy can be found in the scientific field. See e.g. S. Cornielje \& I. Bondarev, Scanning the Scope of Skandia, 26(1) Int'l VAT Monitor 21 (2015). According to the authors, 'it could be argued the ECJ's ruling in the Skandia case is limited to situations in which main establishments are located outside the European Union, and it might also be argued that there is no technical VAT reason to trat the that 'new preliminary questions seem necessary in this respect'.

20 European Commission, Value Added Tax Committee, supra n. 17, at 16.

21 Ibid., at 17 .

22 European Commission, VAT Expert Group, supra n. 18, at 25. 


\section{A bRIEF DESCRIPTION OF THE VAT GROUPING SCHEME APPLICABLE IN SPAIN}

In the particular case of Spain, Article 11 of the VAT Directive was implemented into the national legislation by using a technique that could be defined as sui generis, quite controversial and absolutely different from that employed by the great majority of Member States. It should be noted at this point that, irrespective of minor differences, the VAT grouping schemes that are currently applicable in the European Union appear to be based on a common premise: the non-existence of intra-group transactions for VAT purposes with the understanding that they are conducted between different parts of the same entity and, therefore, do not fall within the scope of VAT. $^{23}$

Quite different from the non-liability system suggested by the European Commission, the VAT grouping scheme that is applicable in Spain is based on the consideration of intra-group transactions as being fully subject to VAT even though the specific treatment of those transactions will depend on the choice of the group itself. This is due to the fact that the Spanish VAT Act (Law 37/1992) establishes a special grouping scheme based on two different modalities or levels (fully voluntary for the VAT group $)^{24}$ : the so-called basic modality that only entails the aggregation of the individual VAT results in a common VAT return submitted by the group and (b) the so-called advanced modality that combines this feature with a particular treatment of intra-group transactions.

\section{I Basic Modality}

The basic modality of the VAT grouping scheme that is applicable in Spain is based on three elements:

(1) All transactions that are conducted by the members of the group, whether they are intra-group transactions or transactions with third parties, are subject to the general rules on VAT.

(2) Under the special regime, every member of the group must continue to submit an individual VAT return on a periodical basis. VAT claims and payments, however, are exercised by utilizing a common VAT declaration.
This circumstance entails both claims and debts being those of the group (and not of its members).

(3) The right to deduct will be exercised individually by each member of the group.

From a practical perspective, the application of the basic modality does not entail substantial difficulties. Each member of the group will quantify its corresponding claim or debt individually with no particularities with regards to the general rules on VAT. The individual result of each member will subsequently be included in a common VAT return submitted by the group itself. As was noted above, the requirement to submit a common VAT return will not prevent the members of the group from being obligated to submit an individual VAT declaration. ${ }^{25}$

On the basis of the aforementioned fact, it has been pointed out that the basic modality does not accord well with the provisions under Article 11 of the VAT Directive. On the contrary, it appears to be closer to the provisions under Article 395(1) in which the first paragraph refers to the possibility for Member States to 'introduce special measures for derogation from the provisions of this Directive, in order to simplify the procedure for collecting VAT or to prevent certain forms of tax evasion or avoidance'. As a result, the compatibility of the basic modality with EU Law should not be judged considering Article 11 but, instead, Article 395 of the VAT Directive.

This conclusion proves to be fully respectful with the reasoning made by the CJEU in the Ampliscientifica judgment in which a distinction was made between the transposition of Article 11 to national legislation and 'the setting up of a mechanism to simplify VAT declarations and payments which enables, inter alia, companies within the same group to remain separate taxable persons, even where VAT may be consolidated in the accounts of the parent company. ${ }^{26}$

\subsection{Advanced Modality}

The advanced modality of the Spanish VAT grouping scheme combines the obligation to submit a common VAT return (distinctive feature of the basic modality) with a number of specified rules:

(1) A particular rule to calculate the tax base of those transactions conducted between the members of the group.

\section{Notes}

23 The position traditionally defended by the European Commission concerning this issue, therefore, has been generally accepted by the Member States. See European Commission, Communication from the Commission to the Council and the European Parliament on the VAT Group Option Provided for in Article 11 of Council Directive 2006/112/CE on the Common System of Value Added Tax, COM(2009) 325 final (2 July 2009), at 10, https://eur-lex.europa.eu/legal-content/EN/TXT/?uri=CELEX\%3A52009DC0325 (accessed 17 Aug. 2020).

24 In Spain, the voluntary nature of the VAT grouping scheme is double: the scheme is only applicable to those groups of entities that expressly opt for applying the special regime and the group itself is responsible for choosing the specific modality (basic or advanced) to be applied.

25 A similar scheme to the one mentioned can be found in the Italian legislation. Amongst others, see G. Melis \& L. Giancola, Cross-Border VAT Groupings: The Effects of the New Italian Regulation, 58(8) Eur. Tax'n 381-386 (2018).

26 Ampliscientifica (C-162/07), supra n. 1, para. 21 
(2) The consideration of intra-group transactions as a specific sector of business.

(3) The right to renounce all of the exemptions provided for in Article 20 of the Spanish VAT Act (financial services, educational services, medical and health care services, etc.).

(4) The obligation to maintain an analytical information system based on reasonable allocation criteria for goods and services that are used in intra-group transactions.

As can be seen, the key element of the advanced modality lies in the classification of every transaction that is carried out by the members of the group into two main categories, each one subject to a different treatment for VAT purposes:

(a) internal or intra-group transactions to which a number of special rules will be applied.

(b) transactions carried out with third parties that are subject to the general rules on VAT.

According to a common understanding, it is the special treatment of intra-group transactions that allows referring to the advanced modality as an actual VAT grouping scheme under the provisions of Article 11 of the VAT Directive. The problem, however, is that the particular functioning of this modality has always incited concerns regarding its compatibility not only with Article 11 of the VAT Directive but also with the interpretative guidelines provided by the European Court concerning this issue. ${ }^{27}$ Such is the case of the Ampliscientifica judgment in which it was stated that:

treatment as a single taxable person precludes persons who are thus closely linked from continuing to submit VAT declarations separately and from continuing to be identified, within and outside their group as individual taxable persons, since the single taxable person alone is authorized to submit such declarations. ${ }^{28}$

As a result, Article 11 of the VAT Directive necessarily requires 'the national implementing legislation to provide that the taxable person is a single taxable person and that a single VAT number be allocated to the group'. ${ }^{29}$

Far from adapting the CJEU's guidelines on VAT grouping, the Spanish VAT Act does not formally recognize the group as a single taxable person. The entities belonging to the VAT group consequently retain their own status as individual taxpayers. That means, among other results, that they retain their own VAT number, act as independent economic operators, are responsible for issuing the corresponding invoices, and exercise the right to deduct on an individual basis.

Whatever the modality (basic or advanced) decided by the group, therefore, the grouping scheme laid down by the Spanish VAT Act brings about neither the allocation of a single VAT number to the group itself, the disappearance of individual VAT declarations, nor the impossibility to consider each member of the group as an individual taxpayer both within and outside the group. On the basis of these facts, it is easy to understand the common opinion that, if there is one thing that the Spanish VAT grouping scheme does not entail, it is precisely that to which Article 11 of the VAT Directive essentially refers: the consideration of the group as a single taxable person for VAT purposes.

\section{The impact of the Skandia America JUDGMENT ON THE SPANISH LEgAL SYSTEM}

\section{I Background Information}

The dubious compatibility of the Spanish VAT grouping scheme with EU law has caused dissent among authors with regards to the knock-on effects of the Skandia America judgment. According to the decision made by the court in this case, when the fixed establishment of a foreign head office belongs to a VAT group in its state of origin, it is no longer possible to consider both entities (the head office and its branch) as being one and the same taxpayer. Thus, the fact of actually entering the group entails a breakdown of the legal relationship previously existing between them. However, what would occur if the VAT grouping scheme that is applicable in the branch's Member State did not formally recognize the group as a single taxable person? Would the consequences of this fact be the same?

Initially, it could be argued that, as long as the Member State of the branch has implemented Article 11 of the VAT Directive in whatever way and with whatever method, the Skandia America judgment should be applied. As a result, services supplied by a non-EU head office to a Spanish branch that is a member of a VAT group in Spain should be considered as falling within the scope of VAT. In the author's opinion, however, the question is more complicated than it appears to be because it is far from clear that the VAT grouping scheme applicable in Spain is compatible with Article 11 of the VAT Directive.

\section{Notes}

27 The dubious compatibility with EU Law is not the only controversial issue related to the advanced modality of the Spanish VAT grouping scheme. There is also a number of interpretative problems and doubts that are mainly derived from inadequately written legal texts, regulatory paucity, and loopholes in the existing regulation.

28 Ampliscientifica (C-162/07), supra n. 1, para. 19

29 Ibid., para. 20 
It is important to take into consideration, as noted above, that the Spanish VAT Act does not formally recognize the group as a single taxable person. It also does not seem to treat the group as a single taxpayer since: (1) there is no allocation of a single VAT number to the group, (2) intra-group transactions are considered as falling within the scope of VAT, although they are treated in a particular manner, and (3) group members keep their own status of individual taxpayers both within and outside the group. The absence of a single taxable person to which fixed establishments of foreign head offices can belong could prevent the decision made by the CJEU in Skandia America from being transferred to the Spanish legal system.

According to the opinion held by some experts, the reasoning would be as follows. Since there is no single taxable person of which to become a part, fixed establishments located in Spain and belonging to a VAT group in that country would continue to be legally bound to their head offices. As a result, they would continue to be a part of their head office and to constitute a single taxable person with it. ${ }^{30}$ This conclusion, however, is far from resembling that made by the Spanish TEAC in a recent resolution in which the knock-on effects of the Skandia America judgment are considered to be fully applicable to VAT groups constituted under the Spanish VAT Act.

\subsection{The TEAC Resolution of 23 January 2020}

The TEAC resolution of 23 January 2020 describes the case of XY PLC located in Ireland and XYP España, its fixed establishment in Spain. XYP España, which is engaged in the supply of insurance services, is the dominating entity of a VAT group constituted under the Spanish VAT Act. During a number of specific years, the Irish head office supplied its branch with management support services that were considered by the entities involved to fall outside the scope of VAT.

Apparently, such a conclusion was based on two different arguments. First, it is upheld that, according to its branch condition, XYP España has no legal personality of its own. As long as it constitutes a single entity with its head office, the transactions in the main proceedings did not occur between independent entities (FCE Bank doctrine). Secondly, the application of the Skandia America judgment is refused on the basis that VAT groups are not regarded as single taxable persons under the provisions of the Spanish VAT Act. The fact that XYP España belongs to a VAT group in Spain, therefore, should not affect the conclusion deriving from the application of the FCE Bank principles.
Neither of the aforementioned arguments are accepted by the Spanish TEAC. On the one hand, the independence test referred to in FCE Bank leads the administrative authority to uphold that the situation of XYP España as an economic operator is fully equivalent to any other entity with a legal personality of its own that is conducting similar transactions. This is due to the fact that the Spanish branch is (1) functionally autonomous, (2) able to make the necessary decisions to carry out its business, and (3) endowed with the necessary human resources and a risk policy. According to the FCE Bank doctrine, therefore, the Irish head office and its branch in Spain are independent entities so that the transactions occurring between them are entirely subject to VAT.

On the other hand, the Spanish administrative authority demonstrates no uncertainties when referring to the Skandia America judgment as being fully applicable to the case in the main proceedings irrespective of the distinctive features of the VAT grouping scheme that is applicable in Spain and the appearance of individuality that it can suggest at some points. In its view, it would be totally inadmissible for the application of the Skandia America case to be rejected purely and simply as a result of the particular transposition of the VAT grouping provision made by the Spanish legislator. In the most elemental understanding of the European Court as the interpreter of EU Law, it continues, the effects of such a judgment should extend to all EU Member States or, at the very least, to those Member States that have decided to exercise the faculty provided for by Article 11 of the VAT Directive.

The above conclusion naturally arises from a forceful defence of the Spanish VAT grouping scheme as fully respectful with EU law. Such a circumstance would be based on the following aspects:

(a) Consultation to the VAT Committee. According to the provisions under Article 11 of the VAT Directive, the VAT grouping scheme was introduced into the Spanish legislation after consulting the VAT Committee (meeting No 92, 7-8 December 2010).

(b) Consideration of the group as a single taxable person for VAT purposes.

The VAT grouping scheme that is applicable in Spain does not formally recognize the group as a single taxable person. However, the advanced modality of such a regime is entirely based on the consideration of the whole group as a single economic entity that is different from each one of its members.

The treatment of the group as an economic unit derives from the application of a number of specific

\section{Notes}

30 See F. Matesanz \& A. González Martínez, El IVA en los servicios prestados por una casa central a su sucursal, Legal Today (16 Mar. 2020), https://www.legaltoday.com/opinion/ blogs/fiscal-y-legal/blog-sobre-tributacion-indirecta/el-iva-en-los-servicios-prestados-por-una-casa-central-a-su-sucursal-2020-03-16/ (accessed 17 Aug. 2020) and J. A. Barciela Pérez, Sucursales y grupos IVA. El asunto Skandia C-7/13, 10 Carta Tributaria 35 (2016). 
rules concerning tax base, right to deduct, and exemptions. Jointly applied, these rules entail the non-taxation of internal value-added until intra-group transactions have an effect outside the group. From this perspective, the advanced modality of the Spanish VAT grouping scheme leads to a result that is fully respectful with the principle of a single taxpayer provided for in Article 11 of the VAT Directive.

(c) Mechanisms to fight against tax evasion and fraud. Under the Spanish VAT Act, entities belonging to a VAT group retain their own VAT number and continue to submit individual VAT returns on a periodical basis. According to the Spanish TEAC, both consequences are supported by Article 11 of the VAT Directive's second paragraph which authorizes Member States to adopt 'any measures needed to prevent tax evasion or avoidance through the use of this provision'. It must be pointed out, likewise, that the Communication from the Commission on the VAT grouping option provided for in Article 11 of the VAT Directive expressly pointed out that:

From the treatment of a VAT group as a single taxable person, it follows logically that the group can only be identified for VAT purposes by a single VAT number ..., to the exclusion of any other individual VAT number. The use of just one number is dictated by the need, for both the economic operators and the tax authorities of the Member States, to identify with a degree of certainty those who are effecting transactions subject to VAT. The individual identification number of each of the members may still be kept by the tax authorities, but only in order to enable monitoring of the internal activities of the VAT group. ${ }^{31}$

(d) Freedom of choice and principle of subsidiarity. According to the TEAC's reasoning, the special rules on the tax base, right to deduct, and VAT exemptions (in which the advanced modality is based) must be considered as an 'alternative' to the non-liability system for intra-group transactions suggested by the European Commission and implemented by most Member States. The fact that these transactions are encompassed within the scope of VAT but are treated in a particular manner, therefore, is regarded by the administrative authority as fully compatible with Article 11 of the VAT Directive.
First is because the provisions under Article 11 are the only possible basis to the particular rules that are applicable to intra-group transactions. Second is because the application of the principle of subsidiarity that is established in Article 5 of the Treaty on the European Union (hereinafter TEU) allows Member States to complete EU regulation when it is insufficient and scarce. Considering this principle, the obligation to submit individual VAT returns would only be a consequence of the method adopted by the Spanish legislator to exercise the faculty provided for in Article 11 of the VAT Directive.

\subsection{Critical Considerations}

There is no doubt that the grouping scheme that is applicable in Spain demonstrates substantial differences with respect to that applicable in other Member States. As stated by the Spanish TEAC, however, such a circumstance should not necessarily lead to the conclusion that the Spanish VAT grouping scheme is not compatible with EU Law.

In the author's opinion, it is important to keep in mind that, according to Article 288 of the Treaty on the Functioning of the European Union (hereinafter TFEU), directives 'shall be binding, as to the result to be achieved, upon each Member State to which it is addressed, but shall leave to the national authorities the choice of form and methods'. Under this premise, the compatibility of a specific national provision with EU law should be judged in light of the result to which that provision leads irrespective of the specific form and methods chosen by the national legislator.

Notwithstanding the aforementioned statement, it must be admitted that Member States do not have absolute freedom when choosing the way that they implement an EU directive. The rules adopted to that end must always be respectful with the principles of the VAT system (such as the principle of fiscal neutrality) and the objectives of the directive in question. ${ }^{32}$ Additionally, it seems to be that EU case law comes into play in this context in the understanding that it is the CJEU's responsibility 'to give preliminary rulings concerning: (1) the interpretation of treaties; and (2) the validity and interpretation of acts of the institutions, bodies, office or agencies of the Union. ${ }^{33}$

Applied to the Spanish case, this reasoning would support the conclusion that the compatibility of the Spanish VAT grouping scheme with Article 11 of the VAT

\section{Notes}

31 See European Commission, supra n. 23, at 5.

32 According to the Opinion Advocate General Sr. Nilo Jääskinen 27 Nov. 2012, Case C-480/10, Commission v. Sweden, ECLI:EU:C:2012:751 'if a Member State decides to opt for VAT grouping, the conditions thereof must be in conformity with the VAT Directive' (para. 35). Later, he insisted: 'It goes without saying that a Member State's laws on VAT grouping must comply with the purposes of VAT grouping as provided in the VAT Directive. In this respect the Member States do not have any discretion' (para. 47).

33 Article 267 TFEU 
Directive should not be conditioned by the fact that VAT groups are not formally recognized as single taxable persons under Spanish legislation. Instead, this analysis of compatibility would require the clarification of two important aspects. The first would be whether the application of the grouping scheme provided for by the Spanish VAT Act allows an equivalent result to that intended by Article 11 of the VAT Directive to be reached. The second is whether the process for achieving such a result is fully respectful with the principles of the VAT system and the CJEU's guidelines concerning this issue.

Returning to the arguments presented by the Spanish administrative authority to support its final conclusion, it should be remarked that, whatever the practical result, the VAT grouping scheme that is applicable in Spain is clearly distanced from the interpretative criteria given by the CJEU in some important judgments. As noted above, this is the case of Ampliscientifica for which the European Court pointed out that the treatment of the group as a single taxable person (a) precludes its members from continuing to submit VAT declarations separately and from continuing to be identified as individual taxable persons and (b) necessarily requires that a single VAT number be allocated to the group. Surprisingly or not, the Spanish TEAC does not make any reference to this aspect in its resolution. In the author's opinion, however, this question should be taken into consideration when evaluating the compatibility of the national legislation with EU law and, consequently, when analysing the application of the Skandia America judgment to one specific country.

On the other hand, it is also the author's view that the principle of subsidiarity is misunderstood by the Spanish administrative authority. As can be inferred from its reasoning, such a principle would allow Member States to 'complete' EU law when necessary. According to Article 5(3) TEU, however, the principle of subsidiarity allows the Union to act 'in areas which do not fall within its exclusive competence' as long as 'the objectives of the proposed action cannot be sufficiently achieved by the Member States, either at central level or at regional and local level, but can rather, by reason of the scale or effects of the proposed action, be better achieved at Union level'. The interpretation that should be given to such a principle, therefore, appears to be different to that provided by the Spanish TEAC in its recent resolution.

Finally, it could be argued that Skandia America dealt with the services supplied by a non-EU head office to its fixed establishment in Sweden, however, nothing was stated about the treatment that should be given to those same services if they were supplied by an EU head office to its fixed establishment in another Member State. Despite the lack of consensus concerning the field of application of the Skandia America judgment, the Spanish administrative authority seems to pay no attention to the existing differences between both cases.
Perhaps a wider reflection on this issue would be necessary.

\section{Conclusions}

For the first time since the publication of the CJEU's decision in Skandia America, a Spanish administrative authority (TEAC) has spoken out explicitly about the impact of such a judgment on Spain. The resolution in question (23 January 2020) is not free from controversy as it can be considered as an attempt to reaffirm the VAT grouping scheme that is applicable in Spain as fully respectful with EU Law.

In its resolution, the Spanish TEAC concludes that a head office located in Ireland and its fixed establishment in Spain are fully independent from a legal perspective so that transactions that are conducted between them fall within the scope of VAT. The TEAC's decision is based on two complementary arguments. On the one hand, the facts in the main proceedings reveal that the Spanish branch carries out an independent economic activity. According to the FCE Bank doctrine, therefore, it is no longer possible to consider that the Irish head office and its fixed establishment in Spain are part of the same entity for VAT purposes. On the other hand, the fixed establishment belongs to a VAT group in Spain. In accordance with the conclusion reached by the CJEU in Skandia America, this fact entails a breakdown of the previously existing legal relationship between the fixed establishment and its head office.

The reasoning made by the Spanish administrative authority to support its final conclusion does not leave the reader indifferent. According to it, three main elements would clarify all of the uncertainties concerning the compatibility of the Spanish VAT grouping scheme with EU law:

(1) The fact that the VAT Committee was consulted prior to introducing such a particular scheme into the national legislation.

(2) The principle of subsidiarity provided for in Article 5 TEU which supposedly empowers Member States to complete EU law when necessary.

(3) The equivalence, from the point of view of the results they lead to, between the Spanish VAT grouping scheme and a system based on the nonliability of intra-group transactions.

In the author's opinion, however, there are some important aspects that could debilitate the aforementioned arguments. The most important of them is that, whatever the practical result it leads to, the Spanish VAT grouping scheme is clearly distanced from the interpretative guidelines offered by the CJEU in Ampliscientifica and other relevant judgments. As one author pointed out, in the 
event of the Spanish VAT grouping scheme being carefully analysed by the European Court, this fact would clearly be an impediment to guaranteeing its survival in a possible clash with the VAT Directive. ${ }^{34}$

In order to ensure legal certainty, the author asserts that greater orthodoxy could be reasonably demanded when transposing EU Directives or incorporating EU rules to national legislation. This requirement would necessitate avoiding the use of 'imaginative' formulas that could be contrary to EU law. The alternative, meanwhile, would entail serious and negative consequences for both Spanish tax authorities and taxpayers.

\section{Notes}

34 L. Delgado Mompó, Los grupos de entidades de crédito y la tributación consolidada en el IVA, 101 Perspectivas del Sistema Financiero 51 (2011). 